\title{
Istinbáth
}

Jurnal Hukum dan Ekonomi Islam

ISSN 1829-6505 E- ISSN 26549042 vol. 19, No. 2. 2020 p. 221-469

Available online at http://www.istinbath.or.id

\section{BLESSING IN DISGUISE TEORI RECEPTIE: DAMPAK TEORI RECEPTIE PADA TRADISI PENYALINAN DAN PENULISAN ULANG MANUSKRIP HUKUM ADAT DAN UNDANG-UNDANG KERAJAAN ISLAM NUSANTARA}

\author{
Anis Masykhur \\ Fakultas Syariah UIN Syarif Hidayatullah Jakarta \\ anis.masykhur@uinjkt.ac.id
}

\begin{abstract}
The political policy of the Dutch colonialists in the late 19th and early 20th centuries had followed up on Snouck Hurgronje's recommendations, especially the relationship between Islam and politics and between Islam and adat. One of the recommendations was that Islam must be separated from the political aspect. In terms of relations with customary law, Islamic law can only be enforced when it be recognized by customary law, which is then known as the receptie theory. The implementation of this theory had been clearly of negative value for the existence of Islamic law. However, the positive side cannot be ignored. Some of the policies carried out by the colonizers were mobilizing the kingdoms in the archipelago to record the acts of kingdoms or applicable customary law by transmitting manuscripts from previous works. This research is a study of customary law documents and statute manuscripts those have been enforced in several Islamic kingdoms by looking at the writing, promulgation and re-copying period. The analysis is equipped with a historical approach. The findings of this study that after the acceptance of the receptie theory, rewriting of customary law documents was most intensive and its peak when it was recorded in 45 volumes adatrechtbundels. Volume I was first printed in $1910 \mathrm{AD}$. By that, the Government emphasized that the law that had been applied was a customary law. Whereas by featuring the customary law, in essence it also accentuated the Islamic law.
\end{abstract}

Keywords: transmission, receptie theory, customary law, manuscript.

Abstrak: Kebijakan politik penjajah Belanda di akhir abad 19 dan awal abad 20 adalah menindaklanjuti rekomendasi kajian Snouck Hurgronje terutama dalam kontek hubungan Islam dengan politik dan hubungan Islam dengan adat. Salah satu rekomendasinya adalah Islam harus dipisahkan dari aspek politik. Dalam hal relasi dengan hukum adat, hukum Islam baru dapat diberlakukan 
ketika tidak bertentangan dengan hukum adat atau dapat pengakuan dari hukum adat, yang kemudian di kalangan ahli hukum adat dikenal dengan teori receptie. Implementasi teori receptie ini bernilai negatif bagi eksistensi hukum Islam. Namun demikian, sisi positifnya tidak bisa diabaikan. Beberapa kebijakan yang dilakukan penjajah adalah memobilisasi kerajaan-kerajaan di nusantara untuk melakukan transmisi naskah berupa penyalinan, penulisan ulang dan pembukuan kitab-kitab undang-undang kerajaan dan hukum adat yang berlaku saat itu. Penelitian ini merupakan studi dokumen naskah hukum adat dan naskah undang-undang yang pernah diberlakukan di beberapa kerajaan Islam Nusantara dengan mencermati masa penulisan, pengundangan, dan penyalinan ulang. Dalam analisisnya dilengkapi dengan pendekatan sejarah. Temuan penelitian ini menyatakan pasca penerimaan teori receptie, pelaksanaan penulisan ulang dokumen hukum adat cukup intensif dan mengalami puncaknya ketika dibukukan dalam adatrechtbundels yang berjumlah 45 jilid. Jilid I dicetak pertama kali pada tahun 1910 M. Dengan pembukuan tersebut, Pemerintah Belanda ingin menegaskan bahwa hukum yang berlaku di masyarakat adalah hukum adat. Padahal, dengan mengunggulkan hukum adat, pada hakikatnya mengunggulkan hukum Islam juga.

Kata Kunci: transmisi, teori receptie, hukum adat, manuskrip

\section{A. Pendahuluan}

Kebijakan pemerintah atas wilayah Hindia Belanda sejak terbitnya nasihat Souck Hurgronje (1857-1936) sangat merugikan umat Islam. Pada tahun 1923, Snouck menuangkan pandangannya tentang agama Islam di nusantara berupa De Islam in Nederlandsch Indie. Ia menyatakan bahwa Islam masih bercampur dengan peradaban orang Hindu yang membawa agama Islam ke wilayah nusantara dari India. Ia juga mengemukakan sebuah konsepsi bahwa hukum Islam dapat diberlakukan sepanjang tidak bertentangan dengan hukum adat atau diterima oleh hukum adat. Konsepsi ini kemudian dikenal dengan sebutan teori receptie. Menurut teori ini, posisi hukum adat terkesan lebih superior dibanding hukum Islam, sehingga hukum Islam baru bisa diterima keberlakuannya jika diterima terlebih dahulu oleh hukum adat. ${ }^{1}$

Pada tahun 1929, nasihat Snouck tersebut menjadi sebuah sistem yang kemudian dituangkan dalam Indische Staatregeling (IS) Pasal 134 ayat (2) 2 :

1 Munawir Syadzali, 'Landasan Pemikiran Politik Hukum Islam Dalam Rangka Menentukan Peradilan Agama Di Indonesia', in Hukum Islam Di Indonesia; Pemikiran Dan Praktik, ed. by Tjun Surjaman (Bandung: Rosda Karya, 1991), p. 45; Sajuti Thalib, Receptio A Contrario, 2nd edn (Jakarta: PT Bina Aksara, 1985), p. 13.

2 Thalib, p. 38. 
Dalam hal terjadi perkara perdata antara sesama orang Islam akan diselesaikan oleh hakim agama Islam apabila keadaan tersebut telah diterima hukum adat mereka menghendakinya dan sejauh tidak ditentukan lain oleh ordonansi.

Pasal di atas adalah perubahan dari Pasal 134 ayat (2) Stbl. 1925: "Kalau terjadi perselisihan perdata antara sesama penduduk inlander atau penduduk yang dipersamakan dengan mereka, diputuskan oleh kepala agama atau kepala adat mereka menurut undang-undang agamanya atau adat aslinya.” Sementara di dalam Stbl. 1929 Pasal 221 ditegaskan bahwa hukum Islam dikeluarkan dari lingkungan tata hukum Hindia Belanda.

Pada tahun-tahun selanjutnya, kebijakan pemerintah Belanda makin terlihat mempersempit ruang Islam, terutama "Islam Politik." Pada tahun 1937 dikeluarkanlah Stbl. 1937: 116 yang isinya bahwa Peradilan Agama di Jawa dan Madura hanya berwenang memeriksa perkara perkawinan saja, sedangkan perkara waris yang selama berabad-abad menjadi kewenangannya diserahkan kepada pengadilan pemerintah. ${ }^{3}$

Secara kasat mata, kebijakan yang didasarkan pada teori receptie jelas merugikan umat Islam Indonesia, karena ditindaklanjuti dengan pelbagai kebijakan yang meminggirkan umat Islam. Sejarah tentu tidak bisa dirubah dan umat Islam tetap menjalani sejarah dengan mengambil makna positif dari sebuah kebijakan, dengan merujuk pada sebuah kaidah 'ma la yudraku kulluh la yutraku kulluh' atau dengan redaksi yang berbeda 'al-maysur la yasquth bi al-ma'sur' yang artinya perkara yang mudah (bisa dikerjakan) tidak bisa dianggap gugur (kewajibannya) karena adanya perkara yang sulit. ${ }^{4}$ Meskipun di tingkat implementasinya pada masa awalawal kemerdekaan Republik Indonesia, teori tersebut dinyatakan batal dengan sendirinya, terlebih ketika rumusan Piagam Jakarta dalam sila ke-1 Pancasila diebutkan "Ketuhanan Yang Maha Esa dengan kewajiban menjalankan syari'at Islam bagi pemeluk-pemeluknya". Namun tidak dipungkiri bahwa teori tersebut pernah diterapkan dalam sejarah nasional bangsa ini. ${ }^{5}$

Salah satu yang luput dari perhatian para pengkaji adalah bahwa pada kisaran tahun setelah tersosialisasikannya teori tersebut yang selanjutnya terimplementasikan dalam kebijakan pemerintah Hindia Belanda, terdeteksi terjadi peningkatan kepedulian pemerintah atas perlindungan dokumen-dokumen penting hukum adat nusantara. Pemerintah Hindia Belanda menggalakkan penyalinan ulang

3 Thalib, pp. 58-60.

4 Taqiyyuddin Al-Khishny, Kitab Al-Qawa'id Jilid 2, ed. by Abd Al-Rahman bin Abd Allah Al-Sya'lan and Jibril bin Muhammad Al-Bushaily (Riyad-Saudi Arabia: Maktabah Al-Rusyd, 1997), pp. 48-49.

5 Dialektika dan dinamika teori-teori tentang relasi hukum Islam dengan hukum adat dapat dibaca dalam Thalib, pp. 4-63. 
dan kodifikasi naskah-naskah yang disinyalir sebagai hukum adat. Kesimpulan ini diambil dari banyaknya naskah yang ditemukan dalam kolofonnya ditulis pada akhir abad ke-19 atau awal abad ke -20. Di antara naskah yang didapat peneliti adalah Salasila Kutai, Undang-Undang Baraja Niti, Undang-Undang Simbur Cahaya, Panji Salatin, dan lain-lain.

Pertanyaan penelitian yang berkenaan dengan tradisi penyalinan dalam pernaskahan ini sebagai berikut; pertama, bagaimana implementasi politik hukum penjajah pasca teori receptie. Kedua, bagaimana dampak implementasi teori receptie terhadap proses transmisi manuskrip hukum adat yang di dalamnya tentunya terdapat dokumentasi hukum Islam.

Penelitian ini merupakan studi dokumen atas manuskrip hukum adat dan undang-undang yang pernah diberlakukan di beberapa kerajaan Islam Nusantara, seperti naskah Salasila Kutai, Undang-Undang Baraja Niti dan Panji Salatin (Kerajaan Kutai Kartanegara), UU Simbur Cahaya (Kesultanan Palembang), Hikayat Banjar dan Undang-Undang Sultan Adam (Kesultanan Banjar, Kalimantan Selatan) dan Undang-Undang Adat Kesultanan Jambi. Pendekatan sejarah dipergunakan sebagai pelengkap untuk menganalisis terutama berkaitan dengan informasi masa penulisan, masa pemberlakukan dan masa penyalinan/penulisan ulang.

Dengan pendekatan tersebut, dua pertanyaan penelitian di atas dapat dijelaskan dengan tuntas, mengingat politik hukum yang pro kepada hukum adat saat itu.

\section{B. Tradisi Transmisi Pernaskahan}

Dalam tradisi pernaskahan, dikenal istilah transmisi yang memiliki makna penurunan (transmission). Istilah penurunan ini dibagi ke dalam dua jenis yakni penyalinan dan penyaduran. Kedua aktifitas tersebut dilakukan atas teks yang telah ditulis oleh pengarangnya. Yang dimaksud dengan penulisan adalah bagaimana naskah pertama kali ditulis oleh penulis (author)-nya. Sedangkan penurunan adalah penulisan ulang dari naskah asli karena beberapa pertimbangan seperti dimaksudkan untuk dimasyarakatkan atau memang untuk kepentingan diperbanyak.

Penulisan manuskrip pada umumnya dilakukan bersamaan dengan adanya kepentingan atas naskah tersebut, seperti para ulama generasi awal yang menulis beberapa kitab untuk mendukung dakwahnya, baik dakwah kepada para raja maupun kepada masyarakat langsung. Seperti naskah Tajus Salatin (mahkota para Raja) karya Bukhari Al-Jauhar seorang ulama dan sastrawan Melayu abad 16-17 M. Kitab ini merupakan hadiah kepada Sultan Aceh, Sultan Alaudin Riayat Syah (1589-1604 M). Kitab ini menjadi karya sastra pertama yang membicarakan tentang etika politik, 
kepemimpinan dan manajemen pemerintahan. Samsuddin Al-Sumatrani (w. 1630 M/1039 H) dengan karyanya Nur al-Daqaiq. Karya Ar-Raniry yang menulis Tuhfah al-Mursalah ila Ruh al-Nabi, al-Haqiqah al-Muwafiqah li al-Sharî 'ah al-Muhammadiyah mir'atu thullab bersamaan dengan kepentingannya sebagai syaikhul Islam saat itu, karena ia menjabat juga penasihat kesultanan pada masa Sultan Iskandar Muda. ${ }^{6}$

Dalam proses transmisi, ada dua jenis proses transmisi. Pertama, transmisi teks melalui penyalinan dalam arti teks sebuah naskah diturunkan ke dalam naskah lainnya dengan cara penulisan kembali teks tanpa merubah bahasa, aksara, dan bentuk teks yang digunakan dalam naskah sebelumnya. Kedua, transmisi teks melalui penyaduran dalam arti teks sebuah naskah diturunkan ke dalam naskah lainnya dengan cara penggubahan kembali teks ke dalam bahasa, aksara, dan atau bentuk teks yang berbeda dari naskah sebelumnya.

Dalam aktifitas proses penyalinan, si penyalin kadang melakukan kesalahankesalahan yang berujung kepada tahrif (kesalahan kecil penulisan huruf atau peletakan huruf yang salah), korupsi (kerusakan teks) atau sejenisnya. Dari sinilah perlunya kritik teks.

Penting sekali untuk mengetahui proses transmisi teks dalam sebuah naskah. Hal ini erat kaitannya dengan penentuan kasus salah tulis yang terjadi dalam kegiatan menyunting ataupun menyalin sebuah naskah atau dikarenakan tidak banyak naskah yang sampai pada para peneliti saat ini adalah teks otograf (ditulis penulisnya). ${ }^{7}$ Dengan demikian, sudah semestinya ada beberapa perbedaan kasus salah tulis yang terjadi dalam sebuah naskah hasil dari transmisi teks melalui penyalinan dengan transmisi teks melalui penyaduran.

Tidak dipungkiri bahwa tradisi penyalinan yang diprakarsai Belanda jelas mendukung kepentingannya. Mu'jizah dan Maria I. Rukmi mengemukakan temuan tersebut dalam hasil penelitiannya, meski terbatas penelitiannya di Residen Riau. Sebagai contoh adalah von de wall, seorang asisten residen Riau pada tahun 1855 dan Walbeehm, seorang Menteri dan juga penghulu di Riau. Mereka banyak mengumpulkan naskah, dan kadang meminta bantuan oranglain untuk menyalinnya. Setelah selesai, naskah tersebut dipelajari dan bahkan ada yang dikirimkan ke Akademie Delft sebagai bahan kajian dan pendidikan bagi orang-orang Belanda yang akan dipekerjakan. ${ }^{8}$ Peneliti menyampaikan bahwa tradisi transmissi tersebut

6 Muhammad Ishom and Syaeful Hadi, 'Syekh Syams Al-Din Al-Sumaterani', Ensiklopedi Islam Nusantara Edisi Intelektual Muslim (Direktorat Jenderal Pendidikan Islam Kementerian Agama, 2017), pp. 459-67.

7 Muhammad Abdullah and others, Pengantar Filologi (Semarang, 2019), p. 38.

8 Lebih detail baca hasil penelitiannya yang telah dibukukan dalam Mu'jizah and Maria Indra Rukmi, Penelusuran Penyalinan Naskah-Naskah Riau Abad XIX; Sebuah Kajian Kodikologi (Jakarta: Fakultas Sastra Universitas Indonesia, 1998), p. 132. 
marak digalakkan pada abad 19. Transmissi naskah ini juga digalakkan oleh kalangan istana.

\section{Politik Hukum di Masa Kolonial}

Merujuk kepada pendapat Ismail Sunny, sebagaimana dikutip oleh Syifa dkk bahwa yang dimaksud dengan politik hukum adalah proses penerimaan keberlakuan hukum hingga munculnya keyakinan akan kewajiban untuk melaksanakannya terutama secara yuridis formal dalam institusi negara. ${ }^{9}$ Hukum dan politik adalah dua hal yang tak terpisahkan. Hukum menjadi instrumen politik untuk mengatur perjalanan sebuah organisasi besar seperti negara. Tidak aneh jika hukum sering disebut produk politik. Hukum tidak bisa diimplementasikan jika tidak mendapatkan dukungan politik. Begitu juga dengan hukum Islam. Ia tidak akan bisa dikenal masyarakat tanpa dukungan politik.

Politik hukum kolonial di awal-awal berdirinya VOC adalah melakukan akomodasi terhadap hukum-hukum yang telah berlaku di tengah masyarakat, baik hukum adat maupun hukum Islam. Ahli hukum adat seperti van den Berg melakukan kajian hubungan antara hukum adat dan hukum Islam yang kemudian muncul teori yang dikenal dengan teori receptio in complexu, di mana hukum adat baru dapat diberlakukan ketika tidak bertentangan atau diterima oleh hukum Islam. Dalam bahasa lain, hukum Islam sudah berlaku untuk pemeluk agama Islam dan hukum adat berlaku untuk masyarakat asli. Tokoh penggagas teori ini adalah Solomon Keyzer (1823-1868) dan van den Berg (1845-1927). Teori didasarkan pada hasil amatan atas praktik masyarakat menjadikan hukum Islam atau hukum adat sebagai landasan perilakunya.

Dari paradigma yang demikian itu, maka ketika Belanda mendirikan lembaga peradilan agama yang disebut dengan Priestrraad (secara harfiah berarti Pengadilan Pendeta), ruang lingkup wewenangnya dalam menyelesaikan perkara di antara orang Islam diselesaikan menurut hukum Islam

Dalam perkembangan selanjutnya, ketika posisi Belanda makin kuat dalam mengkooptasi masyarakat Indonesia namun sering berhadapan dengan komunitas Islam. Kecurigaan pemerintah Hindia Belanda terhadap Islam mencapai puncaknya ketika para pejabat pemerintah Hindia Belanda mulai melakukan kritik terhadap peraturan-peraturan yang dikeluarkan melalui penjelasan tentang hukum adat di Indonesia (het indishe adat recht). Belanda kemudian mengangkat Snouck Hurgronje (1857-1936) sebagai penasihat untuk wilayah Hindia Belanda dan selanjutnya

9 Syifa and Nabila Saifin, 'Politik Hukum Islam Era Kesultanan', Jurnal Reflektika, 13.1 (2017), 1-19 (p. 3). 
menugaskannya untuk melakukan kajian ulang atas hubungan Islam dan adat. Pada akhirnya hasil kajian tersebut menelorkan teori yang dikenal dengan teori receptie. Teori ini memosisikan hukum Islam serasa "lebih rendah" dibanding dengan hukum adat, karena dinyatakan bahwa hukum Islam baru dapat diterima jika tidak bertentangan dengan hukum adat atau diterima oleh hukum adat. Sudah barang tentu, para intelektual muslim banyak yang menolak teori receptie, sampai-sampai ada yang memberikan label teori iblis. ${ }^{10}$

Penamaan teori receptie ini muncul akibat rekomendasi Snouck Hurgronje setelah melakukan berbagai kajian dan kemudian berimplikasi pada keluarnya kebijakan pendataan hukum adat yang berlaku di nusantara. Teori receptie muncul di pertengahan abad ke-19. Jika dikait-kaitkan dengan peristiwa lain di belahan nusantara ini, pertengahan abad ke-19 adalah masa krisis yang menimpa pemerintah Hindia Belanda pasca peperangan melawan Pangeran Diponegoro yang dikenal oleh sejarahwan dengan sebutan Perang Jawa. ${ }^{11}$ Perang ini dianggap sebagai perang terbesar abad itu dan merugikan ribuan golden, hingga Belanda harus menyerahkan wilayahnya kepada penjajah lain, seperti Inggris. ${ }^{12}$

Pasca perang ini, Belanda terpaksa harus mengubah strategi perangnya, dengan landasan kajian yang mendalam. Snouck termasuk yang ditugaskan untuk menjalankan hal itu, yang kemudian muncul teori receptie.

Pada tahun 1859, Pemerintah Hindia Belanda mulai turut campur tangan dalam urusan keagamaan, bahkan diperintah untuk mengawasi gerak-gerik ulama dan juga aktivitas keagamaannya. Dalam rekomendasi Snouck, sebagai penguasa, Belanda harus memiliki kebijakan menangani pribumi (inlandsch politiek) untuk menguasai dan memahaminya. Maka dalam politik hukum Belanda atas daerah jajahannya tidak terlepas dari strategi devide et impera. ${ }^{13}$ Salah satu bentuknya adalah Belanda membenturkan Islam dengan adat. Selain itu, gerak "Islam politik" dibatasi.

Dalam perkembangannya, mulailah pemerintah belanda mengubah beberapa peraturan yang dikeluarkan sebelumnya terutama pasal $75 \mathrm{RR}$ berubah menjadi pasal 31 IS. Pasal 78 RR yang semula tidak mengalami perubahan, pada tahun 1885 juga dirubah dengan pasal 134 IS. Pada akhirnya dikeluarkan Stbl 1929 Nomo 221

10 Ruang lingkup dinamika dan dialektika teori relasi hukum Islam dengan hukum adat ini dapat dibaca lebih lengkap dalam Thalib; Implementasinya dalam konteks hukum modern dapat dilihat dalam Ratna Lukito, Pergumulan Antara Hukum Islam Dan Adat Di Indonesia (Jakarta: INIS, 1998).

11 Peter Carey, Asal-Usul Perang Jawa; Pemberontakan Sepoy \& Lukisan Raden Saleh, ed. by Rahmat Widada, 1st edn (Yogyakarta: LKiS, 2004); Ira M Lapidus, Sejarah Sosial Ummat Islam Bagian Ketiga (Jakarta: PT Raja Grafindo Persada, 2000), pp. 321-22.

12 Mengenai cerita kerugian ini bisa dibaca dalam Agus Sunyoto, Atlas Wali Songo; Buku Pertama Yang Mengungkap Wali Songo Sebagai Fakta Sejarah, 8th edn (Jakarta: Penerbit Pustaka IIMAN, Pustaka Trans Pustaka dan LTN PBNU, 2018).

13 Ahmad Rofiq, Hukum Islam Di Indonesia (Jakarta: PT Raja Grafindo Persada, 1997), p. 17. 
yang menyatakan bahwa hukum Islam sudah tidak berlaku kecuali diterima oleh hukum adat. Pasal 134 IS ini menjadi rujukan formal berlakunya teori receptie. ${ }^{14}$

Dalam konteks kebijakan "mengunggulkan" hukum adat di atas, hemat penulis, adalah kelengahan pemerintah Hindia Belanda yang menganggap bahwa undang-undang kerajaan tersebut dianggap sebagai hukum adat murni.

Sehingga kesimpulannya salah, bahwa hukum Islam baru berlaku jika diakui oleh hukum adat. Padahal, dalam kenyataannya yang ditulis itu sendiri adalah hukum Islam yang sudah tidak menggunakan bahasa-bahasa asal ajaran Islam, namun ia telah diterjemahkan dalam bahasa lokal.

\section{Hukum Adat adalah Hukum Islam}

Masa pengendapan ajaran Islam di tengah masyarakat yang berlangsung sangat lama menjadikan ajaran-ajaran Islam terpateri sebagai satu kesatuan dalam perilakunya. Sehingga, sulit membedakan antara mana ajaran Islam dan mana adat. Islam yang masuk ke wilayah nusantara diperkirakan sejak abad ke-7 masehi yang tersosialisasikan melalui jalur kebudayaan serta perdagangan, tidak melalui jalur kekuasaan. Adanya makam Fatimah binti Maimun di Gresik menunjukkan bukti awal masuknya Islam tersebut. Islam baru memakai jalur kekuasaan pada abad ke14 yang diawali dengan pendirian kesultanan Demak Bintoro.

Beberapa ahli melakukan kajian yang menggali tentang dialektika dan dinamika adat dengan Islam. Ratno Lukito dengan judul risetnya 'Pergumulan Antara Hukum Islam Dan Adat Di Indonesia' menelusuri beberapa hukum adat dan hukum Islam yang telah bertransformasi dalam hukum nasional. ${ }^{15}$ Mark R. Woodward juga melakukan hal yang serupa yang meneliti praktik keberagamaan pada masyarakat Jogja. Hasil risetnya tersebut dituangkan dalam bukunya yang berjudul "Islam in Java; Normative Piety and Misticism" dan sudah ada dalam edisi terjemahannya. Kesimpulan besar risetnya tersebut adalah bahwa Islam yang dipraktikkan di masyarakat Jawa memang agak berbeda dengan Islam dari sumber aslinya (baca: Arab). Namun, bukan berarti yang dipraktikannya tersebut bukan Islam. Woodward menyatkan bahwa ritual keagamaan yang dilakukan muslim Jawa adalah ajaran Islam juga, namun sudah dilakukan penyesuaian. Hal demikian terjadi karena sifat ajaran Islam yang lentur. Jikalau ada yang menyatakan bahwa ritual tersebut adalah dari-misalnya--Gujarat,

14 Abdul Manan, Pembaruan Hukum Islam Di Indonesia (Depok: Kencana, 2017), p. 317.

15 lebih lengkapnya silahkan baca Lukito. 
dari penelusurannya bahwa tradsi umat Islam di Jawa tersebut tidak ditemukan dari daerah-daerah pembawa ajaran Islam seperti dari Gujarat atau daratan China. ${ }^{16}$

Para peneliti lain juga mengkaji pergulatan hukum adat dan hukum Islam. Muhammad Adil, dosen UIN Raden Fatah Palembang, dalam penelitian disertasinya melakukan kajian persinggungan hukum adat dan hukum Islam dengan objeknya adalah undang-undang Simbur Tjahaya. UU tersebut telah dipraktikkan di Kesultanan Palembang mulai abad 17. ${ }^{17}$ Amir Syarifuddin meneliti bagaimana hukum Islam dalam adat masyarakat Minangkabau. ${ }^{18}$ Kajian tentang pengaruh hukum Islam dalam hukum adat juga dikaji oleh Nurana dkk yang mengkaji tentang UndangUndang Adat Minangkabau. ${ }^{19}$ Ayub Mursalin, dosen UIN Sultan Thaha Saifuddin Jambi meneliti tentang pergumulan hukum adat dalam hukum Islam dalam Undang-Undang Adat Jambi. Tarik menarik dua hukum tersebut telah melahirkan kompromi yang ketika bertransformasi menjadi UU resmi kerajaan juga sesuai dengan nilai-nilai Islam. ${ }^{20}$ Sementara itu Mahrudin meneliti kandungan hukum Islam dalam Undang-Undang Martabat Tujuh Kerajaan Buton. ${ }^{21}$ Abdurrahman mengkaji tentang kandungan hukum Islam dalam undang-undang Sultan Adam Kerajaan Banjar, Kalimantan Selatan. ${ }^{22}$ Tulisan yang lebih mendalam dan tajam dilakukan oleh Ayang Utriza Yakin. Ia mengkaji kandungan hukum Islam dalam Undang-Undang Malaka, ${ }^{23}$ bahkan secara spesifik Ia menguraikan persentuhannya antara hukum Islam dan hukum adat di wilayah Terengganu. ${ }^{24}$

Hampir dalam setiap undang-undang yang pernah diberlakukan di beberapa kesultanan nusantara dicantumkan pasal tentang status hukum syara' dan hukum adat. Hal ini menunjukkan bahwa persoalan adat masyarakat tidak memiliki

16 Lebih lengkapnya silahkan baca Mark R Woodward, Islam Jawa; Kesalehan Normatif versus Kebatinan, 2nd edn (Yogyakarta: LKiS, 2004).

17 Muhammad Adil, 'Simbur Cahaya; Studi Tentang Pergumulan Hukum Islam Dan Hukum Adat Dalam Kesultanan Palembang Darussalam' (Universitas Islam Negeri Syarif Hidayatullah Jakarta, 2009).

18 Amir Syarifuddin, 'Pelaksanaan Hukum Kewarisan Islam Dalam Lingkungan Adat Minangkabau' (IAIN Syarif Hidayatullah Jakarta, 1982).

19 Nurana, Zulyani Hidayah, and Syamsidar, Undang-Undang Adat Minangkabau (Jakarta: Departemen Pendidikan dan Kebudayaan, 1992).

20 Ayub Mursalin, 'Penerapan Sanksi Atas Tindak Pidana Perzinaan, Pembunuhan Dan Pencideraan Di Jambi (Studi Tentang Tarik-Menarik Antara Hukum Adat Dan Hukum Islam)’ (UIN Syarif Hidayatullah Jakarta, 2006).

21 Mahrudin, 'Nilai-Nilai Hukum Dalam Undang-Undang Martabat Tujuh Buton', Jurnal Al-'Adl, 8.2 (2015), 123-39.

22 Abdurrahman Abdurrahman, 'Undang-Undang Sultan Adam 1835 Dalam Perspektif Sejarah Hukum', Al-Banjari : Jurnal Ilmiah Ilmu-Ilmu Keislaman, 12.1 (2015), 165-96 "https: / / doi.org/10.18592/al-banjari.v12i1.453".

23 Ayang Utriza Yakin, 'Hukum Pidana Di Kesultanan Melaka Abad Ke-15 Dan Ke-16 M', KARSA: Jurnal Sosial Dan Budaya Keislaman, 24.1 (2016), 33 "https:// doi.org/10.19105/karsa.v24i1.1007".

24 Ayang Utriza Yakin, 'Dialectic between Islamic Law and Adat Law in the Nusantara; A Reinterpretation of the Terengganu Inscription in the 14th Century', Heritage of Nusantara; International Journal of Religious Literature and Heritage, 3.2 (2014), 293-312. 
pertentangan dengan syariat Islam. Sebuah adat yang dicantumkan dalam pasalpasal berarti dapat dijadikan landasan berperilaku atau mengambil keputusan.

Perhatikan ketentuan dalam Pasal 8.2 UU Malaka yang menyebutkan "hukum Allah" sebagai rujukan dalam penetapan sebuah hukuman:

... Adapun jikalau merdeheka menampar abdi, maka ditikamnya oleh abdi itu, mati merdeheka itu, suatupun tiada salahnya. Tetapi pada hukum Allah, yang membunuh itu dibunuh pula hukumnya, maka adil namanya.

Di antara data penelitian yang menunjukkan landasan bahwa hukum adat adalah hukum Islam adalah fenomena UU Martabat Tujuh Kesultanan Buton. Dalam penelitian Mahrudin, ditemukan 3 (tiga) kitab yang dipelajari oleh masyarakat Buton. Kitab tersebut adalah Tuhfah al-Mursalah ilâ Ruh al-Nabî dan al-Haqîqah al-Muwâfiqah li al-Sharî 'ah al-Muhammadiyah. Kedua kitab tersebut adalah karya Burhanpuri dan Nûr al-Daqâiq karya Syamsuddin As-Sumatrani. Nama 'martabat tujuh' memang merujuk kepada ajaran sufi Ibnu Sina. ${ }^{25}$

Dalam Kesultanan Kutai Kartanegara, hukum adat dan hukum Islam menjadai sumber landasan perilaku masyarakat. Pasal 1 UU Panji Salaten menyebutkan pijakan dasar tersebut. ${ }^{26}$

Yang bernama Kerajaan Kutai Kartanegara Ing Martapura .......berhukum dengan adatnya, Bersyara' Islam dengan Alim Ulama’nya.

Dalam pasal 3 UU Panji Selaten juga ditegaskan sebagai berikut: "Mempunyai hukum dengan adatnya, bersyara' Islam dengan agamanya.", yang selanjutnya dijabarkan mekanismenya dalam pasal 20.

Pasal-pasal di atas diimplementasikan lebih operasional dalam pasal-pasal selanjutnya. Di bawah ini diberikan contoh dua pasal dalam naskah undang-undang kesultanan yang menunjukkan hukum adat, tapi pada hakikatnya adalah diterima sebagai bagian dari hukum Islam.

\section{Pasal Perjudian dalam Pasal 19 UUBN Kesultanan Kutai Kartanegara}

Bunyi pasal 19 adalah sebagai berikut:

25 Mahrudin.

26 Naskah Undang-Undang Panji Selaten ini dapat diperoleh dalam lampiran buku M. Asli Amin, 'Pertumbuhan Kerajaan Kutai Kartanegara Ing Martapura', in Dari Swapraja Ke Kabupaten Kutai (Tenggarong: Pemerintah Kabupaten Kutai, 1975). 
"Jikalau ada orang berjudi dalam negeri tiada harus jikalau tiada kahandak raja harus dirampas jika melawan harus dibunuh tiada boleh berjudi jikalau tiada kahandak raja itu...."

Pasal di atas menjelaskan tentang ketentuan perjudian. UUBN menetapkan bahwa bahwa pada hakikatnya perjudian tidak diperbolehkan kecuali jika ada ijin penguasa. Jika para penjudi melakukan perlawanan atas larangan penguasa, ia dapat dibunuh.

Dalam tinjauan fiqh, penyebutan untuk kata 'perjudian' ini adalah dengan istilah maysir, qimar. Hukumnya dalam ajaran Islam jelas haram (QS Al-Maidah [5]: 90).

Dengan mengutip pendapat Ibn Abbas, Al-Qurthubi memberikan penjelasan bahwa hal-hal yang disebut pada awal ayat tersebut dinilai oleh kitab suci dengan dua nilai yakni (1) 'rijsun' yang berarti murka (sukht), kotoran ('adzirah, aqdzar). Bahkan menurutnya dekat sekali dengan kata 'rijz (dengan huruf zay) yang berarti azab; (2) termasuk perbuatan syaitan, maksudnya adalah dapat menggiring lebih jauh kepada perbuatan setan. Karena disifati dengan dua hal tersebut, maka perintah Allah selanjutnya adalah agar menjauhinya. Dengan adanya perintah tersebut menunjukkan bahwa hal-hal di awal ayat tersebut diharamkan, dengan mengacu kepada sebuah kaidah ushul figh, al-ashlfi al-amri li al-wujud (pada dasarnya perintah itu menunjukkan kewajiban). ${ }^{27}$

Dengan penjelasan di atas, para ulama sepakat akan keharaman perjudiannya. ${ }^{28}$

Redaksi pasal di atas sebenarnya ingin mengakomodasi adat masyarakat lokal (baca: Dayak, Kaltim) yang memiliki momen khusus yang membolehkan pelaksanaan perjudian. Dalam adat masyarakat lokal di wilayah Kutai ada peringatan kematian kedua yang disebut dengan tiwah. Dalam peringatan tersebut ada satu fase yang dikenal dengan minih hantu yakni menjaga jenazah selama satu malam penuh. Selama itu, masyarakat yang ikut berjaga terlibat dalam berbagai permainan, di antaranya main kartu yang dekat dengan perjudian, dan lain sebagainya. ${ }^{29}$ Hingga

27 Abi Abdillah Muhammad ibn Ahmad ibn Abi Bakr Al-Qurthubi, Al-Jami' Li Ahkam Al-Qur'an Juz 8, ed. by Abdullah ibn Abd Al-Muhsin At-Turkey (Beirut-Libanon: Mu’assasah Al-Risalah, 2006), pp. 159-60.

28 Abi Abdillah Muhammad ibn Ahmad ibn Abi Bakr Al-Qurthubi, Al-Jami' Li Ahkam Al-Qur'an Juz 3, ed. by Abdullah ibn Abd Al-Muhsin At-Turkey (Beirut-Libanon: Mu’assasah Al-Risalah, 2006), pp. 437-39.

29 Ada yang menganalisis bahwa tradisi perjudian ini bukan budaya asli masyarakat Dayak. Ia dibawa oleh masyarakat luar yang menjadi 'instrumen' yang dapat membuat warga yang hadir dalam acara adat tiwah ini betah. Lebih lanjut silahkan baca L Dyson and Asharini M, Tiwah Upacara Kematian Pada Masyarakat Dayak Ngaju Di Kalimantan Tengah (Jakarta: Direktorat Jenderal Kebudayaan Depdikbud, 1981), pp. 40-43. 
saat ini, pemainan-permainan yang identik dengan perjudian selalu menyertai upacara kematian tersebut.

Perjudian adalah sebuah kebiasaan yang nyaris selalu ada dalam setiap masa dengan berbagai bentuk, termasuk di masyarakat asli pedalaman Kalimantan tersebut.

Pasal 19 UUBN di atas menunjukkan pesan bahwa pelaksanaan perjudian dimungkinkan legal jika diizinkan oleh raja. Hal demikian ini yang menjadikan muatan pasal 19 di atas menggunakan redaksi perlu adanya "kahandak raja". Jika tanpa hal tersebut, maka akan dirampas, bahkan jika menolak dapat dibinasakan.

Perjudian adalah sesuatu yang diharamkan dalam syariat agama termasuk Islam. Namun, UUBN mengatur dengan memberikan batasan yakni 'boleh' namun harus seizin raja. Jadi redaksi di atas menunjukkan kebolehan yang terbatas atau "larangan koma." 30

Pasal 19 tersebut betul-betul merupakan cerminan masyarakat rakyat Kutai Kartanegara. Ia bisa saja mengesahkan hal-hal yang secara tekstual bertentangan dengan syariat. Namun sebenarnya jika ditelaah lebih jauh mengandung kemaslahatan yang kuat.

Kondisi yang demikian itu hampir terjadi di setiap masa. Di era Indonesia modern, mirip dengan kasus yang pemberian ijin lokalisasi pelacuran seperti Kramattunggak (Jakarta Utara) yang eksis sejak tahun 1970-1999, ditetapkan melalui Surat Keputusan (SK) Gubernur DKI Jakarta No. Ca.7/I/13/1970 per tanggal 27 April 1970 tentang Pelaksanaan Usaha Lokalisasi/Relokasi Wanita Tuna Susila. Tempat lainnya adalah Dolly di Surabaya yang beroperasi sejak tahun 19672014. Tempat ini juga dinilai sebagai komplek lokalisasi terbesar di Asia Tenggara. ${ }^{31}$ Dari sisi syariat jelas diharamkan, namun lokalisasi dimaksudkan untuk mencegah bahaya yang lebih besar. Ada kaidah yang dikemukakan para ulama bahwa aldlarar al-asyadd yuzalu bi al-dlarar al-akhaff yang berarti bahaya yang lebih besar dihilangkan dengan bahaya yang lebih ringan. ${ }^{32}$ Sementara Taqiyuddin Al-Hishny

30 Digunakan istilah "larangan koma" menunjukkan bahwa keharaman perjudian initidak mutlak, karena ada kehendak penguasa. Penguasa dapat mengizinkan jika ada kemaslahatan. Karena penguasa atau pemimpin ketika mengeluarkan sebuah kebijakan pasti berdasar pada kemaslahatan, sebagaimana bunyi kaidah "tasharruf al-imam 'ala al-ra'iyyah manuthun bi almashlahat" artinya kebijakan seorang pemimpin atas rakyatnya itu berdasarkan pada kemaslahatan.

31 Sebutan 'terbesar' ini diambil dari berita beberapa media yang cenderung melabeli dengan status yang sama. Hal ini dikarenakan besarnya 'penghuni' dan juga pelanggan dari berbagai wilayah bahkan negara. Untuk lebih detailnya baca Sari Noviana, Nurtika Fadhilah, and Anis Munika, 'Pengaruh Penutupan Lokalisasi Dolly Dan Jarak Terhadap Aktivitas Ekonomi Warga Sekitar', Jurnal Bisnis \& Teknologi Politeknik NSC Surabaya, 2.1 (2015), 50-55.

32 Ibnu Taymiyah menggunakan redaksi 'wa daf'u syar al-syarrain in lam yandafi'a jami' an'. Dalam kaidah ini, redaksi yang ditampilkan beraneka ragam. Ada yang menggunakan redaksi fa yakhtar syarr al-syarrain»: 'daf'u syarr al-syarrain'; " 'yakhtar ahwana al-syarrain', dan sejenisnya. Untuk membahas jenis kaidah ini, Mushthofa Al-Zuhaily membahasnya setebal 
(w. $829 \mathrm{H}$ ) dengan mengutip qawl 'Izzudin ibn Abdissalam merumuskan kaidah dengan redaksi ikhtimal akhaff al-mafsadatain lidaf'i a'dzamihima. ${ }^{33}$ Dengan dasar tersebut, lokalisasi pelacuran memang diharamkan, tapi dapat diizinkan karena untuk menghindari madharat yang lebih besar.

\section{UU Adat Jambi}

Penelitian yang cukup lengkap mengkaji tentang tarik ulur hukum adat dan hukum Islam pada masyarakat Jambi adalah Ayub Mursalin dalam tesis magisternya yang berjudul "Penerapan Sanksi atas Tindak Pidana Perzinahan, Pembunuhan dan Pencideraan di Jambi; Studi tentang Tarik Menarik antara Hukum Adat dan Hukum Islam" (Jakarta: UIN Syarif Hidayatullah Jakarta, 2006). ${ }^{34}$

Pasal 1 UU Adat Jambi:

Barang siapa tiada menghoekoemkan seperti hoekoem jang ditoeroenkan Allah ta-allah itoe maka ja itoe djadi kafir dan djadi menganiaja manasio dan mendjadi pasik.

Inimenjadipasal dasarpelaksaaanhukum diwilayahkesultananJambi.Meskipun demikian, tidak berarti semua yang telah mereka warisi dari zaman sebelum Islam itu dihapuskan, melainkan tetap diberlakukan selama tidak bertentangan dengan hukum Islam. Di samping Al-Quran dan Hadis masih dipedomani juga tradisi lama yang telah turun temurun dari nenek moyang. Perhatikan pula bunyi Pasal 2:

Adapoen moertabat jang tiada soenji kepada oemat Moehamad itoe doewa moertabat. Sala satoenja sarak yang lazim, dan jang kedoewa adat jang koewat.

Dalam uraian selanjutnya, pertemuan hukum adat dengan hukum Islam dalam menangani persoalan pidana menunjukkan keunikannya. Misalkan dalam hukum qisas, yang hukum asalnya ketentuan pidana pencideraan seperti melukai, mencukil mata, dan sejenisnya dibayar dengan hukuman sejenis (qishas). Begitu pula dalam hukum pembunuhan juga dikenakan hukuman dibunuh. Dalam hukum adat nenek moyang sebelumnya, pemberlakuan hukuman yang setara dalam hal qishas tersebut disebut dengan hukum teliti. Namun, seiring perkembangan zaman, hukuman teliti tersebut dihilangkan.

24 halaman dengan berbagai versi kaidah dari berbagai mazhab. Selanjutnya lihat dalam Muhammad Mushthofa Al-Zuhaily, Al-Qawaid Al-Fiqhiyyah Wa Tathbiqatuha Fi Al-Madzahib Al-Arba'ah Juz 1 (Damaskus: Dal Al-Fikr, 2006), pp. 219-25.

33 Taqiyyuddin Al-Khishny, Kitab Al-Qawaid, ed. by Abdurrahman ibn Abdullah Al-Sya'lan (Riyad-Saudi Arabia: Maktabah Al-Rusyd, 1997), pp. 346-53; Izzuddin bin Abdussalam membahas hal ini dalam bab khusus yakni fasal ' fi ijtima' $i$ al-mashalih al-mujarradah 'an al-mashalih'. Baca lebih lanjut dalam 'Izzuddin Abdul Aziz ibn Abdissalam, Qawaid Al-Ahkam Fi Mashalih Al-Anam Juz 1 (Kairo: Maktabah Al-Kulliyyah Al-Azhariyah, 1991), pp. 93-96.

34 Mursalin. 
Dalam pelaksanaan hukuman bagi pelaku pembunuhan, adat menentukan penggantian dengan bentuk yang lainnya seperti menggunakan binatang ternak sebagai penggantinya. Sebagai contoh adalah hilangnya nyawa diganti dengan cara menyembelih sapi atau kerbau, mencukil mata diganti dengan mencukil mata kelapa, dan lain sebagainya. Yang demikian ini berasal dari hukum adat yang dikenal dengan istilah pampas, yang artinya membayar atau mengganti dengan denda. ${ }^{35}$ Besaran dendanya sendiri adalah setengah dari nilai denda yang telah ditentukan dalam hukum Islam.

Perhatikan bunyi potongan pasal Undang-Undang Adat Jambi sebagaimana dikutip dalam tesisnya di bawah ini:

Adapoen nama pampas itoe setenga dita, maka liat keadaan loekanya dan tinggi rendahnya, dalam soeroetnya, bezaar ketjilnya. ${ }^{36}$

Jadi besar biaya pengganti didasarkan pada kualitas luka; besar kecilnya dan juga dalam dangkalnya. Implementasi hukum pidana di atas memang 'menyalahi' teks Al-Quran. Namun dengan alasan tertentu, dapat ditoleransi.

Kesimpulan dari penelitian-penelitian di atas adalah bahwa pengaruh ajaran Islam terasa sangat kuat dalam perumusan pasal demi pasal undang-undang yang berlaku di sebuah wilayah. Undang-undang tersebut kemudian dianggap sebagai hukum adat yang tertulis. Islam yang tidak mementingkan penonjolan simbolsimbolnya, menjadikannya mudah diadaptasi dan diadopsi begitu saja menjadi hukum adat dan dalam undang-undang tidak dibunyikan secara jelas sebagai hukum Islam, namun sebagai hukum adat. Hampir semua undang-undang kesultanan Islam tersebut telah dikumpulkan bersama hukum-hukum adat asli masyarakat (yang bukan hukum kerajaan Islam) dalam sebuah buku berjilid-jilid tentang hukum adat yang dikenal dengan Adatrechtbundels yang terdiri dari 45 Jilid. Ini-sekali lagimenegaskan bahwa undang-undang yang bersumberkan dari ajaran Islam dianggap sebagai hukum adat.

\section{E. Penulisan dan Transmisi Dokumen Hukum Adat}

Sebagai pelaksanaan atas masukan dan rekomendasi hasil kajian Snouck Hurgronje mengenai perlakuan kepada masyarakat muslim nusantara, pemerintah Hindia Belanda menggalakkan penulisan hukum adat yang berlaku di masyarakat nusantara.

35 Mursalin, pp. 149-51.

36 Mursalin, p. 148. 
Maka beberapa kerajaan marak melakukan penyalinan dan penyaduran atas perintah kerajaan Hindia Belanda yang kemudian muncul banyak manuskrip baik yang bersumberkan dari hukum adat, hukum Islam, ataupun undang-undang kerajaan yang ditulis.

Penyaduran dan penyalinan ulang atas manuskrip marak dilakukan pada akhir abad ke-19 hingga awal abad ke-20. Bersamaan dengan itu, penjajah Belanda melakukan perubahan kebijakan terhadap masyarakat jajahannya.

Di bawah ini adalah beberapa manuskrip adat ataupun undang-undang kerajaan-yang dijadikan (atau dianggap)—hukum adat, yang penulisan dan penyadurannya dilakukan pada tahun yang berbeda-beda.

\section{Hikayat Bandjar, Sumber Informasi Hukum Adat dan Hukum Islam di Kalimantan Selatan}

Pada tahun 1857 ada penelitian yang menceritakan secara rinci isi Hikayat Banjar oleh J. Hageman. Hageman menuangkannya dalam tulisan yang diberi judul 'Contribution to the History of Borneo'. Menurut J.J. Ras, rujukan tulisan ini adalah Hikayat Banjar mirip Resensi I.

Ilmuwan lain yang menulis tentang isi Hikayat Banjar adalah A. Van der Ven yang menerbitkan Notes on the Realm of Bandjermasin. Rujukan tulisan ini adalah mirip Hikayat Bandjar Resensi II, dan seterusnya. ${ }^{37}$

Selanjutnya, jika mencermati masa pemberlakuan Undang-Undang Sultan Adam Kesultanan Banjar dengan masa kenal masyarakat atasnya, juga menarik untuk dianalisa lebih dalam. Sebab Undang-Undang ini menjadi satu-satunya dokumen perundang-undangan yang pernah dimiliki sejak Kesultanan Banjar berdiri pada tahun $1526 \mathrm{M}$. Undang-Undang ini dideklarasikan keberlakuannya pada tahun $1835-1860$ M. Abdurrahman dengan mengutip catatan Eisenberger menyebutkan bahwa di Martapura ada sebuah naskah tulisan tangan yang diperkirakan ditulis pada tahun 1880 M. Ia juga menemukan naskah yang ditulis Tumanggung Soeri Koesoeno Ronggo di Banjarmasin tahun $1885 \mathrm{M}$ yang naskahnya juga ditemukan dalam dokumen residen Banjarmasin yang juga dibuat dengan tulisan tangan. ${ }^{38}$

\section{Salasila Kutai, Sumber Informasi Hukum Adat di Kalimantan Timur}

Tidak jauh berbeda dengan penulisan Hikayat Bandjar adalah penulisan Salasila Koetai yang berisikan cerita masyarakat adat Kutai dan asal usul raja di Kerajaan

37 Johannes Jacobus Ras, Hikayat Banjar, 1ed. by terj. Siti Hawa Salleh (Kuala Lumpur: Dewan Bahasa dan Pustaka Kementerian Pendidikan Malaysia, 1990), pp. 4-5.

38 Abdurrahman, 'Undang-Undang Sultan Adam 1835 Dalam Perspektif Sejarah Hukum', Al-Banjari : Jurnal Ilmiah Ilmu-Ilmu Keislaman, 10.2 (2011), 165-96 "https: / / doi.org/ 10.18592/al-banjari.v12i1.453". 
Kutai yang paling tua, dalam penelitian filologi dan kodikologi Anis dan Bambang, diperkirakan ditulis oleh Enci Muhammad Tayib bin Malim Kamim Kayutangi dan selesai tanggal 21 Dzulhijah 1285 H (atau sekitar 1860-an M). W. Kern menegaskan bahwa naskah ditulis pada masa pemerintahan Sultan Aji Muhammad Sulaiman (1850-1899). ${ }^{39}$ Di dalam pengelolaan kerajaan Kutai Kartenegara ini, dilandaskan pada dua Undang-Undang yaitu Undang-Undnag Panji Salatin dan UU Baraja Niti, yang akan dijelaskan di bawah ini.

a. Undang-Undang Panji Salatin

Jika ditelusuri lebih dalam, penamaan Panji Salatin ini memiliki kedekatan nama dengan naskah perundangan atau nama kitab lainnya, yang di antaranya adalah Tajus Salatin, sebuah nama Kitab Undang-Undang Kerajaan Aceh, yang ditulis ulang (disadur) oleh Bukhari Al-Jauhar pada tahun 1603, seorang ulama dan sastrawan Melayu abad ke 16-17 M. Tajus Salatin adalah sebuah buku panduan manajemen pemerintahan kesultanan Aceh, yang ditulis dan dihadiahkan kepada Sultan Alaudin Riayat Syah (1589-1604 M). Isi dari kitab tersebut banyak diterjemahkan ke dalam berbagai bahasa.

Panji Salatin adalah perundang-undangan yang menjadi panduan manajerial pemerintahan di Kerajaan Kutai Kartanegara. Untuk itu, pemberlakuan Panji Salatin ini diperlukan untuk keberaturan perjalanan pemerintahan, termasuk di dalamnya adalah aturan suksesi kepemimpinan.

Adanya kemiripan dengan naskah lain tersebut dimungkinkan, karena pemimpin Kutai saat itu banyak menjalin hubungan dengan pihak luar negeri. Dalam naskah Salasila Kutai diinformasikan bahwa Cina dan Brunei sudah lama menjalin hubungan dengan kerajaan ini. Orang Cina berdatangan ke wilayah Kutai dengan maksud untuk menyabung ayam, begitu juga dengan Aji Batara Agung yang pergi ke Brunei dalam rangka menyabung ayam..$^{40}$ Motivasi menjalin hubungan dengan negara lain hanya untuk menyabung ayam tentu informasi tersebut diragukan.

Namun demikian, pada era Maharaja Sultan, Raja pernah mengutus anak buahnya untuk mempelajari adat istiadat dan sistem pemerintahan di Kerajaan Majapahit dan diterima dengan baik. ${ }^{41}$.

39 Anis Masykhur and Bambang Iswanto, Studi Tentang Naskah Klasik Nusantara Silsilah Kerajaan Kutai Kartanegara Ing Martadipura (Samarinda, 2006).

40 Cerita Aji Batara Agung adu ayam jago disebut-sebut berulang-ulang dalam naskah Silsilah Kutai ini. Lebih lanjut baca Anonim, Silsilah Kutai Kartanegara (Kutai Kartanegara: Departemen Pendidikan dan Kebudayaan Proyek Penerbitan Buku Sastra Indonesia dan Daerah, 1979), pp. 28-40.

41 Jaelani Harun, Undang-Undang Kesultanan Melayu Dalam Perbandingan (USM Press, 2008), pp. 295-300. 


\section{b. Undang-Undang Baraja Niti}

UUBN ini telah menjadi tolok ukur kejayaan Kesultanan Kutai Kartanegara, disusun dan disahkan sebagai aturan kenegaraan pada masa Aji Sinum Mendapa yang memerintah sejak tahun $1635 \mathrm{M}$. Adanya Undang-Undang ini juga menjadi salah satu bukti menepis keraguan para analis sejarah tentang awal masuk Islam di daratan Kalimantan Timur ini.

Sudah menjadi maklum bahwa informasi Islam masuk ke daratan Kalimantan Timur ini pada tahun $1565 \mathrm{M}$ yakni pada masa raja Mahkota yang dibawa oleh dua orang ulama terkenal yakni Abdul Jawad-yang kemudian dikenal dengan Tunggang Parangan ${ }^{42}$ - dan Abdul Makmur Khatib Tunggal, yang bergelar datuk Ri Bandang. Tidak banyak data yang menginformasikan bahwa proses pengislaman di wilayah Kerajaan Kutai Kartanegara ini menggunakan pendekatan kultural. Jika mencermati dari naskah Salasila Kutai, pendekatan dakwahnya terlihat nyata menempuh jalur kekuasaan. Inilah yang menyebabkan Islam menyebar sangat cepat di Kutai Kartanegara.

Kerajaan ini juga berhasil menyusun Undang-Undang Panji Selaten di samping Undang-Undang Baraja Niti. Undang-undang ini resmi menjadi hukum kerajaan setelah \pm 70 tahun Islam masuk ke tanah bagian timur pulau Borneo ini.

Mengenai kapan dan siapa yang menulis atau menyalin Baraja Niti ini memang sulit untuk mendapatkan informasi yang jelas dan tegas. Harun Jaelani dengan mengutip hasil penelitian yang dilakukan oleh J. Zwager (w. 1864), seorang pegawai Belanda yang pernah tinggal dan mengabdi di Kalimantan Timur. Dia menulis sebuah catatan dalam bahasa Belanda yang kemudian diterjemahkan dalam bahasa Indonesia,"Kerajaan Kutaidi PesisirTimurdan Hal-Ehwalnya dalam Tahun 1853." Tulisan ini diterbitkan pada tahun $1866 .{ }^{43}$ Berdasarkan catatan tersebut, ia menyimpulkan bahwa penulisan undang-undang tersebut dilakukan oleh Pangeran Syarif Sukma Wira bin Syarif Jabar Baaqabah pada tanggal 27 Dzulkaedah 1293 H (4 Desember 1876). Dalam penjelasannya, bahwa Pangeran Syarif ini telah menggabungkan undang-undang tersebut dengan isi kitab Bayan al-Acma terutama dalam bagian ketiga dari undang-undang tersebut. Kitab Bayan Al-Acma adalah karya Syaikh Abdullah Al-Mishri, penulis kitab tentang adab ketatanegaraan. Dengan mengutip penelitian Manique Zaini-Lajoubert, Harun mengatakan bahwa Abdullah Al-Mishri yang menulis kitab Bayan Al-Acma adalah orang yang sama dengan seorang penulis kesusasteraan Melayu yang berjudul Hikayat Mareskalek, Cerita Siam dan Hikayat

42 Disebut "Tunggang Parangan” karena Syaik Abdul Jawad ketika masuk ke wilayah kerajaan Kutai Kartanegara dengan menaiki (tunggang) ikat hiu (parang). Baca lebih lanjut naskah Salasila Kutai.

43 Harun, p. 290. 
Tanah Bali. ${ }^{44}$ Mareskalek adalah nama panggilan masyarakat kepada Maarschalk Herman Willem Daendels, Gubernur Jenderal Belanda di Batavia (1808-1811).

Pandangan bahwa Pangeran Syarif Wira Suma yang melakukan penulisan undang-undang Baraja Niti tersebut di atas didasarkan kolofon pada akhir naskah kitab bayan al-acma tersebut, yakni sebagai berikut:

Pangiran Syarif Sukwa Wira ibn almarhum Syarif Jaafar Baaqabah hijrat annabi shallallah 'alaihi wasallam seribu duaratus sembilan puluh tiga pada ketika itulah menulis surat undang-undang ini di dalam duapuluh tujuh hari bulan Zulqaidah hari Arba' itulah hatamnya $1293 .{ }^{45}$

Kesimpulan Zwager ini merujuk pada data bahwa pada masa muda Sultan AM Sulaiman, yang kemudian bergelar Sultan Muhammad Adil Khalifatul Mukminin (1845-1899), dalam menjalankan pemerintahannya ia dibantu oleh empat orang menteri yang bergelar Pangeran. Salah satu dari pangeran tersebut yang bernama Syarif Jaafar bertugas memberikan pendidikan kepada keluarga kerajaan. Pangeran Syarif Sukma Wira adalah putra dari Syarif Jaafar ini yang diperkirakan melanjutkan pengabdian ayahnya.

Hemat penulis, analisis Harun Jaelani ini banyak kelemahannya jika menyatakan bahwa undang-undang ini baru ditulis pada masa Sultan AM Sulaiman yang memerintah pada pertengahan abad 19. Alasan yang dapat dikemukakan adalah bahwa kecenderungan setiap pemerintahan Islam, langkah yang dilakukan awal-awal adalah menyusun sistem yang akan dijadikan rujukan penyelenggaraan pemerintahan. Maka jarak sejak raja pertama kali memeluk agama Islam dengan masa penyusunan undang-undang tersebut selama \pm 70 tahun adalah masuk akal. Itulah yang disebut oleh Azyumardi Azra dengan istilah 'bahasa politik' Islam. ${ }^{46}$

Argumen yang kedua, penulisan UUBN jika baru dilakukan pada tahun 1876, berarti jarak waktu dengan masa pertama kali Raja Kutai masuk Islam adalah \pm 300 tahun. Masa pengendapan selama 300 tahun adalah tidak lumrah bagi pemerintahan Islam.

Undang-Undang Baraja Niti yang diundangkan oleh Aji Sinum Mendapa pada tahun $1635 \mathrm{M}$, dan berlaku sampai tahun $1960 .{ }^{47}$ Hasil alih aksara UU Baraja Niti

44 Harun, p. 292.

45 Harun, p. 293.

46 Azyumardi Azra, Renaisans Islam Asia Tenggara; Sejarah Wacana \& Kekuasaan, ed. by Idris Thaha, 2nd edn (Bandung: PT Remaja Rosda Karya, 2000), pp. 75-84.

47 Baca lebih lengkap dalam M. Asli Amin, 'Pertumbuhan Kerajaan Kutai Kartanegara Ing Martapura', in Dari Swapraja Ke Kabupaten Kutai (Tenggarong: Pemerintah Kabupaten Kutai, 1975); Baca juga dalam D Adham, Salasilah Kutai, 1st edn (Jakarta: Departemen Pendidikan dan Kebudayaan Proyek Penerbitan Buku Sastra Indonesia dan Daerah, 1981). 
ini diabadikan dalam Adatrechtbundels XXXIX: Gemengd. ${ }^{48}$ Berdasarkan dua data tersebut dapat disimpulkan bahwa sebenarnya Pangeran Syarif Sukma melakukan penyalinan ulang (transmisi), bukan sebagai penulis/pengarang (author) naskah yang diperkirakan telah diberlakukan pada tahun 1635 M. ${ }^{49}$

\section{Undang-Undang Simbur Tjahaya Kesultanan Palembang}

Undang-undang lain yang disosialisasikan secara massif pasca fenomena Perang Jawa adalah Undang-Undang Simbur Cahaya Kesultanan Palembang. Menurut Satria Wijaya dkk, undang-undang ini dicetak dan disebarluaskan di masyarakat dengan teksnya berbahasa Arab Melayu untuk pertama kalinya pada tahun 1987. Padahal menurut sejarah, ia diberlakukan sejak tahun $1630 \mathrm{M}$ sampai dengan $1979 .{ }^{50}$

UU Simbur Cahaya ditulis pada masa Raja Sida ing Kenayan (1636-1651 M) oleh istrinya yang dikenal dengan Ratu Sinuhun. Pada asa awal pemberlakuannya, aturan ini dikenal dengan nama Piagem Ratu Sinuhun. UU ini mengatur hubungan para warga di wilayah pedalaman dengan kesultanan dan berlaku sampai 1979 bersamaan dengan dihapusnya pemerintah marga. Naskah Simbur Cahaya yang terlacak hanya naskah yang ditulis pada tahun 1854, 1862, 1873, 1875, 1876, 1894/ 7 , 1913, 1922, 1933, dan 1939. ${ }^{51}$ Undang-Undang Simbur Cahaya dianggap sebagai hukum adat dan dimasukkan ke dalam Adatrechtbundels XI yang diberi judul "Adat Lembaga in Benkoelen 1910-1911". Ini berarti telah terjadi proses penyalinan ulang (tranmission) secara berulang-ulang. Bahkan pada tahun 1922 ada edisi cetak ulang dalam tiga Bahasa; Belanda, Arab Melayu dan latin.

\section{Undang-Undang Minangkabau}

Naskah Undang-Undang Adat Minangkabau (UUAM) ini adalah Karya Jamaran yang memiliki gelar Datuk Tuah. Naskah UUAM ini pertama kali dicetak pada tahun 1917 yang diterbitkan dalam tulisan Arab-Minangkabau / Melayu (aksara Jawi) oleh sebuah penerbitan di Bukittinggi. Struktur UUAM yang dikaji oleh Nurana dkk ini terdiri dari tiga bagian, yaitu mengenai asal usul masyarakat dan tokohtokoh pemimpin masyarakat Minangkabau disertai dengan ajaran filsafat dan adat

48 Untuk membaca teks UU Baraja Niti secara lengkap dapat dilihat di Anonim, Adatrechtbundels, XXXIV: Gemengd ('s-Gravenhage,: Martinus Njhoff, 1937), pp. 229-342.

49 Harun, p. 290.

50 Satria Wijaya, Sahid Teguh Widodo, and Slamet Subiyantoro, 'Ungkapan Kearifan Kultural Tentang Aturan Adat Bujang Gadis Dan Kawin Dalam Undang-Undang Simbur Cahaya Kesultanan Palembang 1824', Jurnal Kredo, 2.1 (2018), 98111.

51 Penelitian yang cukup tuntas tentang Naskah Simbur Cahaya ini adalah bersumber dari penelitian Muhammad Adil. Baca Muhammad Adil, 'Simbur Cahaya; Studi Tentang Pergumulan Hukum Islam Dan Hukum Adat Dalam Kesultanan Palembang Darussalam’ (UIN Syarif Hidayatullah Jakarta, 2009). 
minangkabau; silsilah keturunan dan kaitan kekerabatan kaum otokrasi Pagaruyung yang sering dianggap sebagai "raja" Minangkabau; dan Adat Minangkabau. ${ }^{52}$

Dengan ketebalan 58 halaman diperkirakan dibuat pada pertengahan abad 18 atau awal abad ke-20. Naskah versi ini masih bisa diakses Surau Parak Laweh, Pariangan, Kecamatan Pariangan, Tanah Datar, West Sumatra, Indonesia. ${ }^{53}$ Ada juga versi naskah dengan ketebalan 170 halaman. Manuskrip ini diperkirakan ditulis pada abad ke-18. Manuskrip versi asli ini masih dapat ditemukan di Surau Gadang Ampalu, Kabupaten Padang Pariaman, Western Sumatra.

\section{Ini Risalah Bernama Periasan Perempuan Bagi Anak2 Perempuan [Jumadil Awal $1337 \mathrm{AH}]$}

Manuskrip ini ditulis pada tahun 1918 dengan Bahasa Melayu dan dengan aksara Jawi (arab pegon).

Risalah ini berisikan etika dan nasihat moral Islam yang dikhususkan untuk seorang gadis. Dalam risalah ini berisi 18 bahasan; yaitu: kewajiban kepada mak bapa-nya (kedua orang tua), kewajiban ta'at dan hormat pada mak bapanya, kewajiban sembahyang lima waktu, sifat-sifat dan kelakuan perempuan beruntung, adat berumah tangga, perihal perempuan yang bersuami, aturan kebajikan di dalam perihal melahirkan anak, perihal larangan memakai mas intan, dan larangan berbuat badi'at percaya pada dukun. ${ }^{54}$

\section{F. Masa Penyalinan Kitab UU Kerajaan Islam Nusantara}

Undang-Undang Kerajaan Islam di Nusantara sebagian besar berdiri mulai pada abad ke-16. Bersamaan dengan itu, semua kerajaan menyusun sebuah kitab undang-undang yang dijadikan rujukan penyelenggaraan kenegaraan dan kebangsaan. Namun, pada perkembangannya kemudian, undang-undang tersebut menjadi landasan perilaku warga kerajaan dan pada akhirnya karena dilakukan secara berulang-ulang maka menjadi kebiasaan yang dikenal juga dengan istilah adat.

Di bawah ini adalah dokumen beberapa naskah yang lahir dan marak ditulis pada abad ke-15 s.d. 19. Namun penyalinan secara massif banyak dilakukan pada

52 Nurana, Hidayah, and Syamsidar, pp. 4-5.

53 Anonim, 'Undang-Undang Minangkabau (Minangkabau Law)', British Library, 2020, p. 58 "https://eap.bl.uk/ archive-file/EAP144-4-17" [accessed 1 November 2020].

54 Anonim, 'Ini Risalah Bernama Periasan Perempuan Bagi Anak2 Perempuan [Jumadil Awal 1337 AH Bersamaan Dengan]’, British Library, 2020. 
abad ke-19 dan awal abad ke-20. Dan diperkirakan masih banyak yang baru disalin setelah Belanda masuk ke wilayah-wilayah kerajaan Islam.

Tabel 1. Matrik Pemberlakuan Naskah Hukum Adat ${ }^{55}$

\begin{tabular}{|c|c|c|c|c|}
\hline No & Nama Undang-Undang & Kesultanan & $\begin{array}{l}\text { Tahun Peng- } \\
\text { Undangan }\end{array}$ & $\begin{array}{c}\text { Tahun } \\
\text { Penyalinan }\end{array}$ \\
\hline \multirow[t]{2}{*}{1} & $\begin{array}{l}\text { Undang-Undang Martabat } \\
\text { Tujuh }\end{array}$ & Kesultanan Buton & Awal Abad ke-17 & Abad ke-19 \\
\hline & Adat-Istiadat Raja Buton & Kesultanan Buton & & Abad ke-19 \\
\hline 2 & $\begin{array}{l}\text { Undang-Undang Sultan } \\
\text { Adam }\end{array}$ & $\begin{array}{l}\text { Kesultanan Banjar, } \\
\text { Kalimantan Selatan }\end{array}$ & 1526 & $1880-1885$ \\
\hline 3 & Simbur Tjahaya & $\begin{array}{l}\text { Kesultanan } \\
\text { Palembang }\end{array}$ & $\begin{array}{l}\text { Abad ke-17 (1639- } \\
1650)\end{array}$ & 1987 \\
\hline 4 & $\begin{array}{l}\text { Undang-Undang Adat } \\
\text { Jambi }\end{array}$ & Kesultanan Jambi & Abad ke-16 & $\begin{array}{l}\text { Menjadi } \\
\text { hukum } \\
\text { adat setelah } \\
\text { Belanda } \\
\text { masuk } \\
\text { tahun } 1823\end{array}$ \\
\hline 5 & $\begin{array}{l}\text { Undang-Undang } \\
\text { Minangkabau }\end{array}$ & & $\begin{array}{l}\text { Pertengahan Abad } \\
\text { ke-18 }\end{array}$ & $\begin{array}{l}1012 \\
\mathrm{H} / 1917 \mathrm{M}\end{array}$ \\
\hline 7 & $\begin{array}{l}\text { Undang-Undang Baraja } \\
\text { Niti }\end{array}$ & $\begin{array}{l}\text { Kesultanan Kutai } \\
\text { Kartanegara }\end{array}$ & 1630 & 1876 \\
\hline 8 & $\begin{array}{l}\text { Risalah Bernama Periasan } \\
\text { Perempuan Bagi Anak2 } \\
\text { Perempuan }\end{array}$ & & & 1918 \\
\hline
\end{tabular}

\section{G. Adatrechtbundels; Puncak Pendokumentasian Hukum Adat}

Adatrechtbundels adalah kumpulan dokumentasi hukum adat yang diresmikan dan dipergunakan oleh masyarakat di seluruh nusantara. Termasuk di dalamnya juga beberapa keputusan pemerintah Hindia Belanda di beberapa wilayah, putusan

55 Matrik ini disusun dari beberapa artikel dalam beberapa jurnal sebagai berikut: Mahrudin; Ras; Adil, 'Simbur Cahaya; Studi Tentang Pergumulan Hukum Islam Dan Hukum Adat Dalam Kesultanan Palembang Darussalam'; Masykhur and Iswanto; Adham; Anonim, Silsilah Kutai Kartanegara; Nurana, Hidayah, and Syamsidar; Masmedia Pinem, 'Martabat Tujuh Dalam Naskah Asrar Al-Khafi, Karya Syaikh Abd Al-Mutalib’, Jurnal Lektur Keagamaan, 10.1 (2012), 121-46; Abdurrahman; Rustam Effendi, 'Struktur Dan Makna Undang-Undang Sultan Adam Pada Masa Kerajaan Banjar Kalimantan Selatan', LITERA, 12.2 (2013), 256-68; Mursalin. 
pengadilan terkait dengan adat, dan termasuk undang-undang kerajaan. Buku ini terdiri dari 45 (empatpuluh lima) bundel/jilid dengan ketebalan kisaran 400 s.d 600 halaman.

Adatrechtbundels volume 1 dicetak pertama kali pada tahun 1910, sedangkan volume ke 45 dicetak pada tahun 1955.

Setiap bundel berisi dokumen hukum adat yang telah diklasifikasikan berdasarkan pulau dan terkecil adalah provinsi. Misalkan saja pada bundel ke-26 berisi tentang hukum adat yang ada di Malaysia yang berada di pulau Kalimantan (Borneo). Sedangkan khusus tentang hukum adat masyarakat nusantara yang ada di pulau Kalimantan didokumentasikan dalam bendel ke-13 dan ke-44. Pada bundel ke13, berisikan dokumentasi hukum adat masyarakat dayak di Sambas dan Pontianak, hukum adat pada umumnya, UU Sultan Adam Banjar Kalimantan Selatan, dan lain sebagainya. Meskipun demikian, dalam satu bendel memuat adat-adat dari berbagai daerah atau propinsi. Jika dalam satu bendel tertulis kata 'gemengd' itu berarti di dalamnya campuran berbagai adat dari berbagai daerah.

Hukum adat yang relatif banyak terdokumentasikan terdapat di tanah Jawa dan Madura yang didokumentasikan dalam lima bundel, yakni bundel yang ke-2, ke-4, ke-14, ke-19, dan ke-34. Tentang adat Jawa juga dimuat pula bersama adat Bali di bundel yang ke 23. Bundel ke-22 dan 32 secara khusus menceritakan tentang adat Sumatera Bagian Selatan. Pencantuman Undang-Undang Simbur Tjahaya terdapat dalam bundel ke-22. Beberapa kategori, kadang menyebut daerah-daerah di luar Indonesia, seperti Bundel ke-21 menyebut tentang adat masyarakat timur yakni Philipina (saat ini), dan disebut pula dalam bundel ke-16 yang memuat hukum adat wilayah Timur dan Philippina. Namun di dalamnya juga mencantumkan beberapa adat istiadat masyarakat Ambon. Sedangkan bundel yang ke-45 mencantumkan adat istiadat di daratan papua. Dalam bendel tersebut dituliskan New Guinea (Papua Nugini).

Perhatikan matrik bundel hukum adat beserta kategorinya di bawah ini:

Tabel 2. Matrik Adatrechtbundels

\begin{tabular}{|l|l|c|l|}
\hline No & \multicolumn{1}{|c|}{ Vol Bundel Buku Adat } & $\begin{array}{c}\text { Tahun } \\
\text { Cetak }\end{array}$ & \multicolumn{1}{|c|}{ Gambaran Singkat Isi } \\
\hline 1 & Adatrechtbundels, Volume 01 & 1910 & Gemengd \\
\hline 2 & Adatrechtbundels, Volume 02 & 1911 & Java en Madoera \\
\hline 3 & Adatrechtbundels, Volume 03 & 1910 & Minahasa \\
\hline 4 & Adatrechtbundels, Volume 04 & 1911 & Java en Madoera \\
\hline 5 & Adatrechtbundels, Volume 05 & 1912 & Gemengd \\
\hline
\end{tabular}




\begin{tabular}{|c|c|c|c|}
\hline 6 & Adatrechtbundels, Volume 06 & 1913 & Sumatra \\
\hline 7 & Adatrechtbundels, Volume 07 & 1913 & Borneo \\
\hline 8 & Adatrechtbundels, Volume 08 & 1914 & $\begin{array}{l}\text { bezorgd door de commissie voor het } \\
\text { adatrecht (Java en Madoera) }\end{array}$ \\
\hline 9 & Adatrechtbundels, Volume 09 & 1914 & $\begin{array}{l}\text { Bezorgd Door De Commissie Voor Het } \\
\text { Adatrecht (Celebes) }\end{array}$ \\
\hline 10 & Adatrechtbundels, Volume 10 & 1915 & Gemengd \\
\hline 11 & Adatrechtbundels, Volume 11 & 1915 & Sumatra \\
\hline 12 & Adatrechtbundels, Volume 12 & 1916 & $\begin{array}{l}\text { Gemengd [West-Java, Midddel-Java, } \\
\text { Minangkabau, Zuid-Sumatra, Minahasa } \\
\text { etc] }\end{array}$ \\
\hline 13 & Adatrechtbundels, Volume 13 & 1917 & Borneo \\
\hline 14 & Adatrechtbundels, Volume 14 & 1917 & Java en Madoera \\
\hline 15 & Adatrechtbundels, Volume 15 & 1918 & Bali en Lombok \\
\hline 16 & Adatrechtbundels, Volume 16 & 1919 & $\begin{array}{l}\text { Bezorgd Door Commissie Voor Het } \\
\text { Adatrecht: Groote Oost En Phippijnen }\end{array}$ \\
\hline 17 & Adatrechtbundels, Volume 17 & 1919 & Celebes \\
\hline 18 & Adatrechtbundels, Volume 18 & 1919 & $\begin{array}{l}\text { Bezorgd Door Commissie Voor Het } \\
\text { Adatrecht: Gemengd }\end{array}$ \\
\hline 19 & Adatrechtbundels, Volume 19 & 1921 & Java en madoera \\
\hline 20 & Adatrechtbundels, Volume 20 & 1922 & Sumatra en Riau \\
\hline 21 & Adatrechtbundels, Volume 21 & 1922 & Groote Ooste En; Philippinen \\
\hline 22 & Adatrechtbundels, Volume 22 & 1923 & Gemengd \\
\hline 23 & Adatrechtbundels, Volume 23 & 1924 & Java en Bali \\
\hline 24 & Adatrechtbundels, Volume 24 & 1925 & Groote Ooste \\
\hline 25 & Adatrechtbundels, Volume 25 & 1926 & Gemengd \\
\hline 26 & Adatrechtbundels, Volume 26 & 1926 & Maleisch Gebied En Borneo \\
\hline 27 & Adatrechtbundels, Volume 27 & 1928 & Sumatera \\
\hline 28 & Adatrechtbundels, Volume 28 & 1927 & Gemengd \\
\hline 29 & Adatrechtbundels, Volume 29 & 1928 & Gemengd \\
\hline 30 & Adatrechtbundels, Volume 30 & 1929 & Register \\
\hline 31 & Adatrechtbundels, Volume 31 & 1929 & Celebes \\
\hline 32 & Adatrechtbundels, Volume 32 & 1930 & Zuid-Sumatra-Djambi \\
\hline 33 & Adatrechtbundels, Volume 33 & 1930 & Gemengd \\
\hline 34 & Adatrechtbundels, Volume 34 & 1931 & Java en madoera \\
\hline 35 & Adatrechtbundels, Volume 35 & 1931 & Sumatera \\
\hline 36 & Adatrechtbundels, Volume 36 & 1933 & Borneo, Zuid-Celebes,Ambon \\
\hline
\end{tabular}




\begin{tabular}{|l|l|c|l|}
\hline 37 & Adatrechtbundels, Volume 37 & 1934 & Bali en Lombok \\
\hline 38 & Adatrechtbundels, Volume 38 & 1936 & Gajo-, Alas- en Bataklanden \\
\hline 39 & Adatrechtbundels, Volume 39 & 1937 & Gemengd \\
\hline 41 & Adatrechtbundels, Volume 40 & 1938 & $\begin{array}{l}\text { uitgewerkte inhoud literatuurlijst 1927- } \\
1937 \text { register op bundels 31-39 }\end{array}$ \\
\hline 42 & Adatrechtbundels, Volume 41 & 1943 & Sumatra \\
\hline 43 & Adatrechtbundels, Volume 42 & 1943 & $\begin{array}{l}\text { Adatrechtbundels XLII: Gemengd: } \\
\text { Bezorgd Door De Commissie Voor Het } \\
\text { Adat-Recht En Uitgevegen Door Het } \\
\text { Koninklijk Instituut Voor De Taal-, Land- } \\
\text { En Volken- Kunde Van Nederlandsch- } \\
\text { Indie }\end{array}$ \\
\hline 44 & Adatrechtbundels, Volume 44 & 1952 & Borneo \\
\hline 45 & Adatrechtbundels, Volume 45 & 1955 & Nederlands Nieuw Guinea \\
\hline
\end{tabular}

Sumber diolah dari Katalog Perpustakaan Nasional, Google Book, dan Perpustakaan Fakultas Ilmu Budaya Universitas Indonesia

Yang menarik untuk dicermati adalah bahwa meski yang didokumentasikan adalah hukum adat, namun sebenarnya tidak selamanya hukum adat murni. Di dalamnya juga ada beberapa undang-undang kerajaan di nusantara UndangUndang Minangkabau, Undang-Undang Kerajaan Malaka, Undang Adat Jambi, Undang-Undang Panji Salaten dan Undang-Undang Baraja Niti milik Kerajaan Kutai Kartanegara. ${ }^{56}$

\section{G. Penutup}

Kebijakan yang berpijak pada hasil kajian akademik memang memiliki daya tahan lebih lama, karena ia tidak sekedar bersifat responsif belaka. Teori receptie yang menjadi landasan penerbitan sebuah aturan pemerintah Hindia Belanda secara kasat mata jelas merugikan umat Islam. Namun, proses ajaran Islam yang telah lama mengalami masa pengendapan dan menyatu dengan perilaku masyarakat

56 Berbagai penelitian yang menyingkap kandungan hukum Islam dalam beberapa dokumen hukum adat atau undang-undang kerajaan Islam antara lain Lukito; Mahrudin; Ayang Utriza Yakin, 'The Register of the Qadi Court "Kiyahi Pêqih Najmuddin" of the Sultanate of Bantên, 1754-1756 CE.', Studia Islamika, 22.3 (2015), 443-86 "https:/ / doi.org/ 10.15408 / sdi.v22i3.2354"; Ayang Utriza Yakin, 'Hukum Pidana Di Kesultanan Melaka Abad Ke-15 Dan Ke-16 M', KARSA: Jurnal Sosial Dan Budaya Keislaman, 24.1 (2016), 33 "https://doi.org/10.19105/karsa.v24i1.1007"; Ayang Utriza Yakin, 'Islamisasi Dan Syariatisasi Samudera-Pasai Abad Ke-14 Masehi', ISLAMICA, 9.2 (2015), 269-94; Adil, 'Simbur Cahaya; Studi Tentang Pergumulan Hukum Islam Dan Hukum Adat Dalam Kesultanan Palembang Darussalam’; Abdurrahman. 
telah dianggap menjadi adat kebiasaan. Hal itu terpotret dalam beberapa naskah undang-undang kerajaan Islam.

Jikalau kebijakan pemerintah Hindia Belanda menganggap undang-undang kerajaan Islam sebagai hukum adat, pada hakikatnya menjadikan hukum Islam sebagai landasan operasional kerajaan. Jika sebuah teori menyatakan bahwa jika adat diterima masyarakat pada umumnya, maka pada hakikatnya yang diterima adalah hukum Islam.

\section{Referensi}

Abdullah, Muhammad, Mudjahirin Thohir, Mohammad Muzakka, and Rukiyah, Pengantar Filologi (Semarang, 2019)

Abdurrahman, 'Undang-Undang Sultan Adam 1835 Dalam Perspektif Sejarah Hukum', Al-Banjari: Jurnal Ilmiah Ilmu-Ilmu Keislaman, 10 (2011), 165-96 "https: / / doi.org/10.18592/al-banjari.v12i1.453"

Abdurrahman, Abdurrahman, 'Undang-Undang Sultan Adam 1835 Dalam Perspektif Sejarah Hukum’, Al-Banjari :Jurnal Ilmiah Ilmu-Ilmu Keislaman, 12 (2015), 165-96 "https: / / doi.org/10.18592/al-banjari.v12i1.453"

Adham, D, Salasilah Kutai, 1st edn (Jakarta: Departemen Pendidikan dan Kebudayaan Proyek Penerbitan Buku Sastra Indonesia dan Daerah, 1981)

Adil, Muhammad, 'Simbur Cahaya; Studi Tentang Pergumulan Hukum Islam Dan Hukum Adat Dalam Kesultanan Palembang Darussalam’ (Universitas Islam Negeri Syarif Hidayatullah Jakarta, 2009)

__ 'Simbur Cahaya; Studi Tentang Pergumulan Hukum Islam Dan Hukum Adat Dalam Kesultanan Palembang Darussalam' (UIN Syarif Hidayatullah Jakarta, 2009)

Al-Khishny, Taqiyyuddin, Kitab Al-Qawa'id Jilid 2, ed. by Abd Al-Rahman bin Abd Allah Al-Sya'lan and Jibril bin Muhammad Al-Bushaily (Riyad-Saudi Arabia: Maktabah Al-Rusyd, 1997)

—_ Kitab Al-Qawaid, ed. by Abdurrahman ibn Abdullah Al-Sya'lan (Riyad-Saudi Arabia: Maktabah Al-Rusyd, 1997)

Al-Qurthubi, Abi Abdillah Muhammad ibn Ahmad ibn Abi Bakr, Al-Jami' Li Ahkam Al-Qur'an Juz 3, ed. by Abdullah ibn Abd Al-Muhsin At-Turkey (Beirut-Libanon: Mu'assasah Al-Risalah, 2006) 
- Al-Jami' Li Ahkam Al-Qur'an Juz 8, ed. by Abdullah ibn Abd Al-Muhsin AtTurkey (Beirut-Libanon: Mu’assasah Al-Risalah, 2006)

Al-Zuhaily, Muhammad Mushthofa, Al-Qawaid Al-Fiqhiyyah Wa Tathbiqatuha Fi AlMadzahib Al-Arba'ah Juz 1 (Damaskus: Dal Al-Fikr, 2006)

Amin, M. Asli, 'Pertumbuhan Kerajaan Kutai Kartanegara Ing Martapura', in Dari Swapraja Ke Kabupaten Kutai (Tenggarong: Pemerintah Kabupaten Kutai, 1975) Anonim, Adatrechtbundels, XXXIV: Gemengd ('s-Gravenhage,: Martinus Njhoff, 1937)

__ ' 'Ini Risalah Bernama Periasan Perempuan Bagi Anak2 Perempuan [Jumadil Awal 1337 AH Bersamaan Dengan]', British Library, 2020

_- Silsilah Kutai Kartanegara (Kutai Kartanegara: Departemen Pendidikan dan Kebudayaan Proyek Penerbitan Buku Sastra Indonesia dan Daerah, 1979)

__ 'Undang-Undang Minangkabau (Minangkabau Law)', British Library, 2020, p. 58 "https:/ / eap.bl.uk/archive-file/EAP144-4-17" [accessed 1 November 2020]

Azra, Azyumardi, Renaisans Islam Asia Tenggara; Sejarah Wacana \& Kekuasaan, ed. by Idris Thaha, 2nd edn (Bandung: PT Remaja Rosda Karya, 2000)

Carey, Peter, Asal-Usul PerangJawa; Pemberontakan Sepoy \& Lukisan Raden Saleh, ed. by Rahmat Widada, 1st edn (Yogyakarta: LKiS, 2004)

Dyson, L, and Asharini M, Tiwah Upacara Kematian Pada Masyarakat Dayak Ngaju Di Kalimantan Tengah (Jakarta: Direktorat Jenderal Kebudayaan Depdikbud, 1981)

Effendi, Rustam, 'Struktur Dan Makna Undang-Undang Sultan Adam Pada Masa Kerajaan Banjar Kalimantan Selatan', LITERA, 12 (2013), 256-68

Harun, Jaelani, Undang-Undang Kesultanan Melayu Dalam Perbandingan (USM Press, 2008)

ibn Abdissalam, 'Izzuddin Abdul Aziz, Qawaid Al-Ahkam Fi Mashalih Al-Anam Juz 1 (Kairo: Maktabah Al-Kulliyyah Al-Azhariyah, 1991)

Ishom, Muhammad, and Syaeful Hadi, 'Syekh Syams Al-Din Al-Sumaterani', Ensiklopedi Islam Nusantara Edisi Intelektual Muslim (Direktorat Jenderal Pendidikan Islam Kementerian Agama, 2017)

Lukito, Ratna, Pergumulan Antara Hukum Islam Dan Adat Di Indonesia (Jakarta: INIS, 1998)

M Lapidus, Ira, Sejarah Sosial Ummat Islam Bagian Ketiga (Jakarta: PT Raja Grafindo Persada, 2000) 
Mahrudin, 'Nilai-Nilai Hukum Dalam Undang-Undang Martabat Tujuh Buton', Jurnal Al-'Adl, 8 (2015), 123-39

Manan, Abdul, Pembaruan Hukum Islam Di Indonesia (Depok: Kencana, 2017)

Masykhur, Anis, and Bambang Iswanto, Studi Tentang Naskah Klasik Nusantara Silsilah Kerajaan Kutai Kartanegara Ing Martadipura (Samarinda, 2006)

Mu'jizah, and Maria Indra Rukmi, Penelusuran Penyalinan Naskah-Naskah Riau Abad XIX; Sebuah Kajian Kodikologi (Jakarta: Fakultas Sastra Universitas Indonesia, 1998)

Mursalin, Ayub, 'Penerapan Sanksi Atas Tindak Pidana Perzinaan, Pembunuhan Dan Pencideraan Di Jambi (Studi Tentang Tarik-Menarik Antara Hukum Adat Dan Hukum Islam)’ (UIN Syarif Hidayatullah Jakarta, 2006)

Noviana, Sari, Nurtika Fadhilah, and Anis Munika, 'Pengaruh Penutupan Lokalisasi Dolly Dan Jarak Terhadap Aktivitas Ekonomi Warga Sekitar’, Jurnal Bisnis \& Teknologi Politeknik NSC Surabaya, 2 (2015), 50-55

Nurana, Zulyani Hidayah, and Syamsidar, Undang-Undang Adat Minangkabau (Jakarta: Departemen Pendidikan dan Kebudayaan, 1992)

Pinem, Masmedia, 'Martabat Tujuh Dalam Naskah Asrar Al-Khafi, Karya Syaikh Abd Al-Mutalib’, Jurnal Lektur Keagamaan, 10 (2012), 121-46

R Woodward, Mark, Islam Jawa; Kesalehan Normatif versus Kebatinan, 2nd edn (Yogyakarta: LKiS, 2004)

Ras, Johannes Jacobus, Hikayat Banjar, ed. by terj. Siti Hawa Salleh (Kuala Lumpur: Dewan Bahasa dan Pustaka Kementerian Pendidikan Malaysia, 1990)

Rofiq, Ahmad, Hukum Islam Di Indonesia (Jakarta: PT Raja Grafindo Persada, 1997)

Sunyoto, Agus, Atlas Wali Songo; Buku Pertama Yang Mengungkap Wali Songo Sebagai Fakta Sejarah, 8th edn (Jakarta: Penerbit Pustaka IIMAN, Pustaka Trans Pustaka dan LTN PBNU, 2018)

Syadzali, Munawir, 'Landasan Pemikiran Politik Hukum Islam Dalam Rangka Menentukan Peradilan Agama Di Indonesia', in Hukum Islam Di Indonesia; Pemikiran Dan Praktik, ed. by Tjun Surjaman (Bandung: Rosda Karya, 1991)

Syarifuddin, Amir, 'Pelaksanaan Hukum Kewarisan Islam Dalam Lingkungan Adat Minangkabau’ (IAIN Syarif Hidayatullah Jakarta, 1982)

Syifa, and Nabila Saifin, 'Politik Hukum Islam Era Kesultanan', Jurnal Reflektika, 13 (2017), 1-19 
Thalib, Sajuti, Receptio A Contrario, 2nd edn (Jakarta: PT Bina Aksara, 1985)

Wijaya, Satria, Sahid Teguh Widodo, and Slamet Subiyantoro, 'Ungkapan Kearifan Kultural Tentang Aturan Adat Bujang Gadis Dan Kawin Dalam Undang-Undang Simbur Cahaya Kesultanan Palembang 1824', Jurnal Kredo, 2 (2018), 98-111

Yakin, Ayang Utriza, 'Dialectic between Islamic Law and Adat Law in the Nusantara; A Reinterpretation of the Terengganu Inscription in the 14th Century', Heritage of Nusantara; International Journal of Religious Literature and Heritage, 3 (2014), 293-312

-, 'Hukum Pidana Di Kesultanan Melaka Abad Ke-15 Dan Ke-16 M', KARSA: Jurnal Sosial Dan Budaya Keislaman, 24 (2016), 33 "https:// doi.org/10.19105/ karsa.v24i1.1007"

_- 'Hukum Pidana Di Kesultanan Melaka Abad Ke-15 Dan Ke-16 M', KARSA: Jurnal Sosial Dan Budaya Keislaman, 24 (2016), 33 "https:// doi.org/10.19105/ karsa.v24i1.1007"

_ ' 'Islamisasi Dan Syariatisasi Samudera-Pasai Abad Ke-14 Masehi', ISLAMICA, 9 (2015), 269-94

—, 'The Register of the Qadi Court "Kiyahi Pêqih Najmuddin" of the Sultanate of Bantên, 1754-1756 CE.', Studia Islamika, 22 (2015), 443-86 "https:// doi. org/10.15408/sdi.v22i3.2354" 